\title{
THE TREATMENT OF VARICOSE VEINS
}

\section{BY INTRA-VENOUS INJECTIONS.}

\section{By}

J.D.P. McLatchie, M.B., C.M. (Ed.)

$$
\begin{aligned}
& ===x==\geq==x==x== \\
& \text { M. D., } 1928
\end{aligned}
$$




\section{INTRODUCT ION .}

The treatment of varicose veins has assumed in recent years an entirely different aspect, ulue chiefly to the work of sicard. He showed that it was possible to cure them in the great majority of cases by means of intra. venous injections and that this cure, provided that certain conditions were observed could be carried out without arenger to the patient.

I have endeavoured in thj.s Thegis to record the results in my own hospital and private practice of the above mentioned treatinent as well as the experience of some of the numerous workers in this portion of the therapeutic field.

With this object in view I have considered the subject under the following heads:

(1) Historical

(2) Preparation ano dosage of the various chemical substances used in the modexn treatment of varices.

(3), Local and general effects of the injections. 
(4) Remarks on the different substances used for intra-venous injection.

(5) Technique.

(6) Results of treatment.

(7) Contra-indications.

(8) Advantages of the method.

(9) Surnary.

(10) Bibliography. 
The beginning of the injection treatment of Varicose veins may be said to date from the year 1851 when Pravaz invented his syringe. Before that date the treatment for their radical cure was surgical, thus Hippocrates ${ }^{2}$ advised multiple puncture of the vein and sald that they should not be cut open as then large ulcers may result.

Celsus ${ }^{3}$ either cut the veins out, or destroyed them by a cautery at red heat after exposing the veins by incision. He said that care must be taken not to burn the edges of the skin incision. Avicenna $a^{4}$ also recommended the cautery. Paulus Aegineta ${ }^{5}$ exposed the vein by an incision and passed a needle with a double thread beneath it. He next opened the vein and allowed as much blood to escape as was desired. He then tied the vein in the upper part of the wound and more blood was evacuated by compressing the limb with the hands. The lower part of the vein was then tied and the part of the vein between the ligatures was either cut or allowed to "drop out" of its own accord. Ambroise Pare ${ }^{6}$ did practically the same operation 
as $P$. Aegineta, only he destroyed the vein between the ligatures with a cautery.

Pravaz used his syringe to inject aneurisms with perchloride of iron and to cure them by coagulating the blood in them.

This idea was soon applied to the treatment of varicose veins and the substances used were such as were considered likely to produce a clot sufficient to obliterate the lumen of the vein.

The great cause of failuse in the earlier applications of this treatment was of course the ignorance of antisepsis, at that period, and as a result septic cornplications, such as local abscesses, sloughs and septic emboli prevented the general adoption of the treatment in spite of the success obtained in many instances.

Members of the Lyons school were the first to use the new method of treatment. Desgranges, Valette? Barrier and Petriquin ${ }^{8}$ injected perchloride of iron into the reins and had some successful results. The treatment initiated by the Lyons school was taken up in 1853 by Chassaignac ${ }^{9}$ of the Saint-Antoine Hospital of Paris. He used the same drug but soon 
gave up the treatment on account of the number of eases in which sepsis ensued.

The use of Perchloride of Iron was given up for a time, especially as in 1854 Desgranges $^{10}$ reported the cure of sixteen cases by the injection of 'Iiqueur Iodotannique' without any symptoms causing anxiety.

The Iiqueur Iodo-tannique was a formula due to Socquet and Gullermond of Lyons and its composition as injected into the reins was:

$$
\begin{aligned}
& \text { Iodine } 5 \text { grammes } \\
& \text { Tannin } 45 \text { grames } \\
& \text { Watex } 50 \text { grames. }
\end{aligned}
$$

the dose usually being 5 - 7 drops.

Desgranges noted that the local reactions were much milder than with perchloride of Iron and he also compared the nature of the clot caused by the two preparations. The Iiqueur Iodo-tannique clot was insoluble in boiling water, but soluble in solutions of Hydrochloric acid and in solutions of potassium and Sodium Salts, while the clot caused by perchloride of Iron was soluble in boiling water and only slightly soluble in alkaline media. Desgranges kept his patients in bed for twelve days, so that his treatment could not be called ambulat- 
ory. Septic infection, however, was still experienced in a more extended use of this substance.

The next step was to try perivenous injections with the object of setting up an inflarmation which would spread to the inner coat of the vein and so cause thrombosis. It was also thought that the risks of septic emboli might be lessened.

The first substance tried was ergot of rye. It was employed by Guyon and others in 1876 with unhappy results and was therefore soon abandoned.

In 1878 Inglisch of Vienna ${ }^{11}$ used $5 \%$ alcohol; Marc Sefe and Broca adopted Bnglisch's method and Broca also modifled it by using $30 \%$ alcohol.

Broca $^{12}$ also tried Pexchloride of Iron and Püi employed chloral liydrate. The results of the perivenous injections were no better than the old, some successes but many failures chiefly due to septic infection. In 1881 Legendre ${ }^{13}$ revired the Liqueur Iodo-tannique method. He modified it by using a. much veaker solution ( 1000 grammes of water instead of the 50 of the original formula) but his results were no better than those obtained by the stronger solution. This method was, however, still used in France by a few medical men, and Delore at the Lyons Congress of Surgery in 1894 expressed his belief in it and also maintained that 
its efficacy was due not to coagulating the blood but to the inflammation set up in the walls of the vein.

In 1904 Tavel 14 of Berne introduced Carbolic Acid. He used a $5 \%$ solution and injected it after ligaturing the internal saphenous vein.

In 1908 schiassi ${ }^{15}$ injected into the vein a solution composed of:

$$
\begin{array}{ll}
\text { Iodine } & \text { gramme } 1 \\
\text { Pot.Iodid gramne } 1.60 \\
\text { Water } & \text { grammes } 100 .
\end{array}
$$

He divided the vein below the knee and through a cannula tied into the distal end of the divided vein, he injected 30-50 c.c. of the above solution. He then ligatured the vein below the point of the cannula. In 1916 Iinser of Iubigen ${ }^{16}$ used Perchloride of Mercury. He treated many cases with it, and there is no doubt that this method was a great advance. It however caused nephritis, stomatitis, enteritis, in a certain number of cases.

The medical profession, nevertheless, as a whole, looked askance at the method of treating varicose veins by intravenous injections, and it was not until the work of Sicard especially and of Genevrier that the method has 
become established on a firm basis and has obtained general recognition.

Sicard while giving Luargol intravenously, in 191617 noticed that the veins into which he injected that drug, became obliterated and that no emboli were produced. He considered this result to be due to the Soda part of the Salt, and in 1917 he began his intravenous injection treatment of varices by injecting Carbonate of Soda. In 1919 he showed before a medical society ${ }^{17}$ his first series of cases, and in 1920 he published his first paper ${ }^{18}$ on the subject. With increasing experience, however, he found that this substance was too caustic and as a result its injection required so much care that it was not suitable for general use. After trying various salts, such as Chloride of Calcium, Hyposulphite of soda, etc. he finally chose Salicylate of soda 19 and this is still the drug that he recominends for treatment.

Génévrier also figures prominently in the development of this treatment. In 1917 he noticed the obliteration of veins following the intravenous introduction of Quinine. He published his method of treatment in $1921^{20}$ 
and a later paper in $1922^{21}$ Montpellier and Lacroix published their results with Biniodide of Mercury in $1921^{22}$ and in $1924 \mathrm{~J}$. Troisier 23,24 introduced Citrate of Soda. The above and various other substances will be considered in the following section. 
On the preparation and dosage of the various cherical substances employed in the modern treatment of Varices.

The substances are of course used in solution: the water employed should be twice distilled and carefully sterilised. An appropriate amount is put up in glass ampoules and these are again sterilised.

The arnoules are usually made of neutral glass. The solutions usually keep well in this. The only drug that causes any difficulty is Sod Salicylate. It should not be put up in araber coloured glass as with that, owing to the Iron in the glass, a precipitate is formed of Salicylate of Irun. Even when the glass is clear and neutral some change takes place. This is indicated by a slight brownish discolouration of the solution. The nature of this change is not understood. It can be prevented by adiing Sod. Thiosulphate to the solution in the proportion of 1.5000. The solution of SodSalicylate then remains perfectly cleax. This modified solution is the one I always use. 
Pure crystallised Carbonate of soda.

This is not generally used now on account of its powerful caustic action. If injected by mischance into the perivenous tissues, or if blood mixed with it leaks from the vein, extensive sloughing may result.

It is usually put up in $10 \mathrm{c.c}$. ampoules containing a' $10 \%$ solution. For the first injection a $5 \%$ solution should be used. If necessary a $15 \%$ solution raay be employed.

Before injecting the Sod. Carb. solution, a needie fitted to a 2 c.c. syringe containing normal saline ought to be passed into the vein. The normal saline is then injected and if it remain entirely in the vein, the syringe is detached and a 10 c.c. syringe containing the Sod. Carb. solution is attached to the needle and the solution injected.

Sodium Salicylote.

This is the drug which is most generally used at present. It is put up in 3 strengths, $20 \%-30 \%$ and 40\%. Each ampoule contains 2 c.c. or 3 c.c. Of course larger sizes may be used if the operator wishes to do so. At the first satting only 2 c.c. of the $20 \%$ solution should be injected. 
At subsequent sittings the maximum amounts to be injected are:

$$
\begin{aligned}
& 8 \text { - } 10 \text { c.c. of the } 20 \% \text { solution. } \\
& 8 \text { c.c. " " } 30 \% \text { " } \\
& 5-6 \text { c.c." " } 40 \% "
\end{aligned}
$$

These amounts are not absolute, but form a good working guide.

\section{Quinine.}

Génévrier's formula is:

$$
\begin{array}{lr}
\text { Ouinine Hydrochloride (neutral) } & 4 \text { gramaes } \\
\text { Urethane } & 2 \text { grammes } \\
\text { Aq. J\$still. } & 30 \mathrm{c.c} .
\end{array}
$$

The urethleane being used for its anaesthetic properties.

The quinine crystallises out so that the ampoules

have to be warmed immediately before use.

This difficulty can be overcome by using the Bihydrochloride of quinine. This remains in solution and avoids the necessity of previous warming of the ampoules.

$$
\text { For the first injection not more than a total }
$$

amount of 2 c.c. should be used. This is introduced 
by multiple punctures at intervals of 2-4 inches, each site receiving $\frac{1}{4}-\frac{1}{4}$ c.c.

At subsequent sittirigs amounts up to 6 c.c. can be used each time.

If the vein is large, as much as 1 c.c. can be introduced at one place if necessary.

The double Hydrochloride of quinine and urea is used by Vandier 25 . He employs it in strengths of $5 \%$, $10 \%$, 12\%, $15 \%$ and $20 \%$. He started using it on the suggestion of Le Blaye. The combination had of course been long used in surgery on account of its local anaesthetic effects and it was thought that this would lessen the painful effects of intravenous injections. He states that it does so but apart from this there is not much evidence of any advantage over Genevxier's formu1a, and in the weaker dilutions its action seems uncertain, but he says he has never failed to get a reaction with the $20 \%$ solution.

In a later publication 26 vandier has given up the use of the weaker solutions and uses solutions varying in strength from $15-30 \%$.

In the few instances in which I have used this preparation there was an entire absence of any cramp like 
pains.

Biniodide of Mercury (Montpellier).

1. Usual formula is

$\begin{array}{lr}\text { Biniodide of Hercury } & 1 \\ \text { sodium lodide } & 1 \\ \text { Aq. distill. } & 100\end{array}$

2. Another formula is:

Biniodide of Mercury. 50 grames

Sod. Iodid .50 grames.

Sod. Chlor. .50 "

Aq. distizl. $\quad 100$ c.c。

For the first dose 1-2 c.c. are injected. As much as 6 c.c. of solution No. 1 (the one usually employed) has been injected at one sitting, but this caused salivation and diarrhea. Solution No. 2 being weaker can be gुiven in larger doses.

Sodium Citrate (Troisier).

The formula for this is:

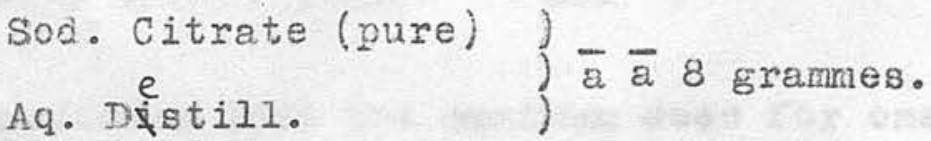

Fornerly this was the quantity injected at each sit- 
ting, except the first, when about 4 c.c. were injected. Through each puncture 1-2 c.c. were introduced, the punctures being about $3-5$ centimetres apart. At the present tirne, the usual strength to begin with is only about $5 \%$ and the strength is increased according to the results. It is rarely necessary to use the $100 \%$ solution. When the patient notices a saity taste in his mouth, no more should be given.

Sodium Chloride. This was introduced by Linser 27,28 after he gave up the use of Hyd. Perchlor. He used a 15-20\% solution. The quantity injected at one sitting is usually 5-10 c.c. Larger quantities can be used if necessary as it is not toxic. For patients of an advanced age it may be necessary to use a stronger solution.

Meisen's Solution. Meisen first used Sod. Sal. in $20 \%-30 \%$ solution in $1925^{29}$. but in $1927^{30}$ he modified his formula to a solution composed of

$$
\left.\begin{array}{ll}
\text { Sol. Sod. Salicylate } 25 \% \\
\text { sol. Sod. Chlorid. } & 10 \%
\end{array}\right\} \bar{a} \bar{a}
$$

He found by experience that the maximum dose for one sitting ought not to exceed $10 \mathrm{c} . \mathrm{c}$. 
14.

Glucose. T. Remmoraky and R. Kantor ${ }^{31}$ introduced glucose. They used a $50 \%$ solution, in amounts of 5-10 c.c. for one sitting. Glucose can also be used in strengths up to $66 \%$.

A preparation called Calorose has been introduced by G. Nobl 32 . It consistis of equal quantities of Dextrose and Levulose in distilled water. The strength of the solution is 50\%. As these sugars are not poisonous, larger quantities than $10 \mathrm{c.c}$. can be given.

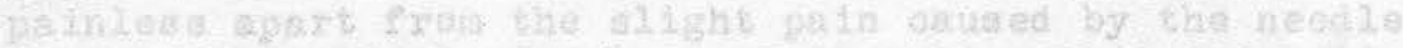

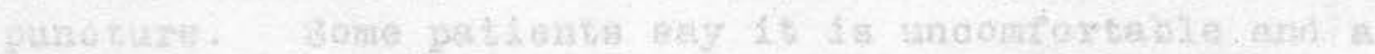

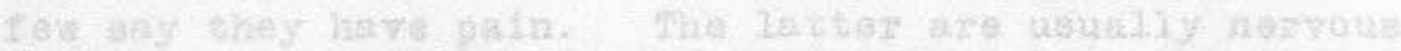

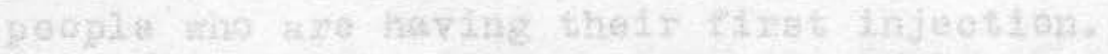

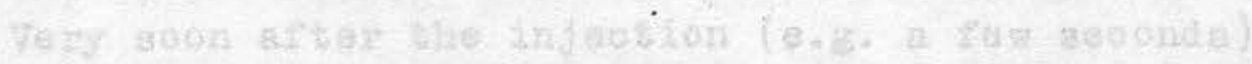

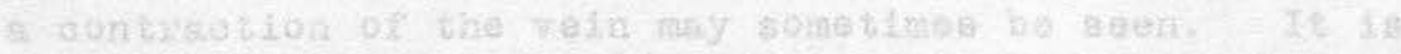

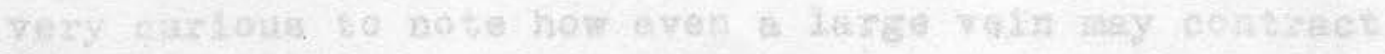

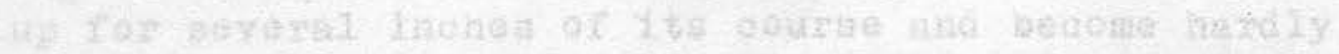

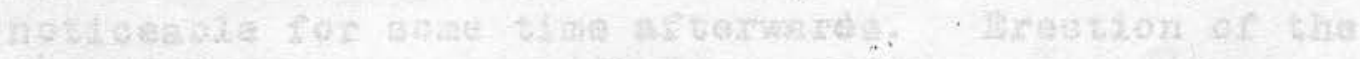

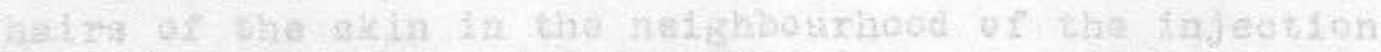

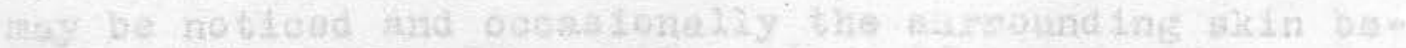

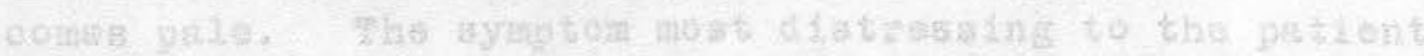


Remarks on the local and general effects of the injections.

The effects alluded to in this section are those which follow a strictly intravenous injection. Should the solution be injected into the tiasues outaide the vein, severe inflammation is apt to follow, and even sloughing tay resujt. The resulting ulcers take a long time to heal and may result in disfiguring scars. As a rule the strictly intravenous injection is painless apart from the slight pain caused by the needle puncture. Some patients say it is uncomfortable and a few say they have pain. The lacter are usually nervous people who are having their first injection.

Very soon after the injection (e.g. a few seconds) a contraction of the vein nay sonetimes be seen. It is very curious to note how even a large vein may contract up for several inches of its course and become hardy noticeable for some time afterwards. Frection of the hairs of the skin in the neighbourhood of the injection may be noticed and occasionally the surrounding skin becomes pale. The symptom most distressing to the patient 
16.

is, however, "cramp", and this occurs chiefly with the Sod. Salicylate injections. The cramp comes on a few seconds after the irjection, and indeed it may come on while a solution of 40 is being given. The patients usually say it shoots down the les into the foot, but some have described it as also passing up the thigh. It is most probably a reflex due to irritation of the nerves in the venous wall. It is always bearable and only lasts a minute or so at the most in my experience. It is reliered by elevating and supporting the leg, or by allowing the patient to lia down.

Another $10 c a l$ effect is great swelling of the vein in the neighbourhood of the injection. This is seen especially when quinine is injected into a vein which runs over bony surfaces, e.g. foot and front of tibia. It is rather alarming when observed for the first time, but no - anxiety need be felt as the swelling passes away in a few days at most.

Wxtravasation of blood may occur into the extravascular tissues near the site of zuncture. This is of course due to the leaking of blood from the puncture in the vencus wall. Strictly speaking it ought not to occur, but it is not always possible to avoid it even with the greatest 
care. It causes temporary disfigurement merely, unless some of the injected substance is mixed with it. In that case a swelling will remain for a considerable time, and even necrosis may result.

On the day following the injection, if the result is successful the vein for a variable distance feels tender and hard. The degree of tenderness varies of course with the amount of inflammatory reaction of the venous wal1. This is sometines quite severe, and then the skin over the affected part is red and feels hot. At other times when the reaction is slight, hardy anything is noticed locally except a hardening of the vein. The patient often says that the $l e g$ is rather stiff for the next two or three days, especially on getting up in the morning. These results are very seldom sufficiently severe to prevent the patients from following their usual occupations, and one patient told me that she even did her "physical jerks" all through the treatment.

The application of a fomentation at night relieves the tenderness in the usual run of moderately severe reactions. In a few cases the reaction may require rest in bed for a day or two. This is especially noticed with quinine. These acute symptoms usually disappear 
18.

in 4-5 days, and in the vast majority of cases need cause no anxiety.

When the inflammation has passed off, there may be pigmentation of the skin over the part. This may take a long time to go and in some cases it never quite disappears. After a variable time, e.g. 2-3 months, the vein is transformed into a fibrous cord.

The general effects except in a small percentage of cases, are quite negligible.

Palpitations, faintness, usually occur during the earlier injections, and are due to fear. Noises in the ears and giddiness may occur after Sod. Sal. and Quinine, and some patients say that they have a bitter taste in the mouth soon after quinine has been injected. Skin eruptions have been noticed in a few cases, e.g. urticaria and a patchy erythema.

G. Delater ${ }^{33}$ has referred to some of these effects in a recent article. He says that in about $\frac{1}{2} \%$ of his cases he has noticed slowing of the pulse, cold sweats and nausea. These symptoms occurred at the second or third injection, although nothing had happened at the first injection. He mentions that 
the dose given was 4 c.c. $20 \%$ sod. Sal in each leg. On substituting quinine, the reaction did not occur. As regards these cases I think that the patient is rather apprehensive for the first 3 or 4 sittings. The first injection of 2 c.c. $20 \%$ sod. Sal. with only one puncture does not affect them so much as perhaps the next two sittings, when more punctures are made. The symptoms may be due to an idiosyncrasy to Sod. Sal. but it is not unreasonable to consider them as due to emotion to a large extent.

He also mentions a case where $40 \%$ Sod. Sal. when injected caused arrest of circulation and respiration for a short time. Another case which had a history of an old phlebitis of the deep reins received 2 injections of 2 c.c. $30 \%$ sod. on different occasions. The first time she felt dazed on the way home; the second time she was found unconscious in the street and had to be taken home in a car. She recovered completely. These seem to be examples of idiosyncrasy to the drug. He mentions also 5 cases in each of which 1 gramme of quinine was injected at one sitting. Soon afterwards they complained of a bitter taste in the mouth and had noises in the ears, palpitation, sweats and nausea. They became 
restless, and had waves of heat. The pulse was feeble but regular. There was a slight rise of temperatures, no albumen in the urine. An attack of urticaria supervened. Complete recovery followed. These are evidently also examples of idiosyncarsy to the drug injected.

Aimes of Montpellier ${ }^{34}$ states he always uses quinine for his injections. In one case where quinine had failed he twice used $30 \%$ sod. Salicylate at 8 days interval. He gave a third injection this tine of $40 \%$ sod. Sal. and the patient was attacked with dyspnca, a sense of oppression and a generalised urticaria which lasted about 2 hours.

Jorgensen ${ }^{35}$ had a case (a woman aged 45 ) in which he gave three injections each of 5 c.c. $20 \%$ Sod. Salicylate with satisfactory results as far as the veins were concerned and without any constitutional symptoms. A week after the last injection a further dose of 5 c.c. $20 \%$ sod. Salicylate was given. Two or three hours after this injection the patient had headache. noises in the ears, shivering and free perspiration. Accompanying these symptoms, there was codema of the face and hands. Later urticaria appeared mainly on the face and lower limbs. Petechiae were also found 
on the insiae of the thighs.

There were also nausea and vomiting, quick and deep breathing and the pulse was quickened.

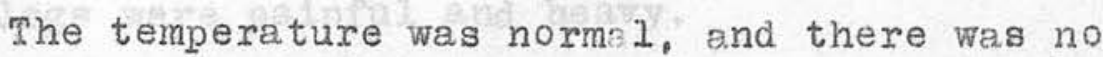
albumen, blood or sugar in the urine.

After twenty-four hours the whole condition cleared up leaving the patient in an exhausted condition. Previous to the injections this patient had been taking aspirin in rather large doses, but details of the amount taken are not given. The only case in my own practice in which I have seen unusial symptoms was a wornan aged 60 who had ext, ensive varicose veins of both legs and an ulcer on the inner side of the right ankle.

The ulcer was healed by antiseptics and dressings of Unna's Zinc Gelatine and she then agreed to have the veins obliterated. Into a prominent vein leading from the ulcer but well away from it 1.5 c.c. Quinine $\bar{c}$ Urethfane solution was injected. The injection was strictly intravenous and caused no trouble at the time, but when seen a few days later the leg was swollen and cedematous and the veins could not be seen. The left leg was therefore treated with the same quantity of the 
22.

Quinine and Urethfane solution with an exactly similar result.

There were no general symptoms but the patient said her legs were painful and heavy.

The swelling disappeared in a few days with rest and bandaging. A solution of Sod. Salicylate was used instead of quinine and there were no further troublesome sequelae. 
Remarks on the different substances used for Intra-venous injection.

Sodium Carbonate: As this is seldom used now owing to its severe effects, it need not be discussed.

Sodium Salicylate: I consider this to be on the whole the best substance to use. The curative inflammatory reaction is generally speaking, mild, and should some of the solution be injected perivenously there is not much risk of necrosis of the tissues. of course this only applies to small quantities that anyone might inadvertently inject. If any large quantity is so injected, it usually means that the operator is unskilful.

for the first injection never use more than $2 \mathrm{c.c}$. This is injected by a single puncture.

The tissue reaction is thus tested, and also an idea is obtained of any idiosyncrasy of the patient to the drugi.

Should the $20 \%$ solution be successful, continue with that strength, of course giving larger quantities if there is no reaction use the $30 \%$ solution, and then 
the $40 \%$ solution if necessary.

Where the desired effect is not obtained, it is always advisable to work up rapidly to the higher strengths. If the use of a weaker solution is persisted in, the result is merely thickening of the venous wall without obliteration. The treatment can be given two or three times a week. This of course depends on the extent of the varicose veins and the reaction set up. When the $40 \%$ solution fails to cure, a different substance ought to be tried. An important point in the injecting of sod. Salicylate is the occurrence of a characteristic stinging pain when any, of the solution escapes into the perivenous tissues. This ought to be a warning to the operator to stop the injection. To wait untiI he observes a swelling caused by an extravascular injection is a very likely method of producing a slough.

I do not advise ading cocaine for one of its modifications) to the solution. Its anaesthetic effects may abolish the warning signal of pain when the injection is extravascular.

Quinine. The first injection should not be more than 2 c.c. for the same reasons as given under Sod. Salicylate. The great advantage of quinine is the extent of area that 
can be treated. This is a great saving of time. Unfortunately the local reaction is more severe than with Sod. Salicyl. and if many injections are made it may be necessary for the patient to lie in bed for a few days: This in my experience is a very rare event in those treated by sod. Salicylate.

Quinine does not give rise to the so-called "cramps" which so frequently follow sod. Salicylate, and there is not at once so much pain when it is injected extravenous1y, but in that case the pain is usually very severe during the next three or four days.

Quinine in my experience is very useful in those cases where Sodium Salicylate has failed. In a case of large and extensive varices, where I could not get a satisfactory result with sod. Salicylate, a change to Quinine brought about an immediate success.

Quinine should not be used in cases of pregnancy on account of the danger of causing abortion, or during 'menstruation, as it may cause griping pains.

As a general rule none of the substances used cause clotting of the blood. The result of mixing them with the blood is to sause haemolysis, but with 
quinine, especially after two or three punctures, the blood in the syringe may clot. The clots are small but quite obrious to the naked eye. On microscopic exanination one finds in addition to the clots, the red

dobris of the, corpuscles, from which the hamoglobin has disappeared. collected in masses. With a similar mixture of blood and sod. Salicylate no clots or masses of debris are to be seen. The only formed cells left in both cases are the leucocytes.

Biniodide of Mercury: This salt gives quite good results in tine majority of cases, but its action is uncertain. Sometimes a large extent of vein may become obliterated; at another time no result is obtained. Its injection does not cause "cramp". If injected into the tissues it gives rise to a very severe reaction and may cause extensive sloughing.

Trven with intravenous injection a very violent reaction may occur, the affected vein becoming very swollen and red, with much pain for several days. In some cases the reaction is very wide-spread and is accompanied with cedema of the foot. 
There is at times a rather curious effect. The reaction at the original point of injection is followed by successive zones of inflamnation extending one above the other along the course of the vein. This is rather alarming, but they have never been known to pass into the deeper veins. They remain limited to the offected rein.

Sometimes the reaction is delayed even a week or more, so it is not advisable at the beginning to give an injection oftener than once in 10-14 days.

It is most advisable to examine for signs of renal disease before using this drug.

I do not recommend this arug for routine use on account of the above mentioned reactions, but it is useful if Sod. Salicylate and Quinine fail and when there is a history of syphilis.

Citrate of Soda: The intravenous injection of this is attended with only slight cramp. The reaction may be very painful and necessitate rest in bed. Citrate of soda does not present any special advantages, but is useful when owing to idiosyncrasy etc., it is inadvisable to use quinine or Sod. Salicyl. 
Sodium Chloride: This acts very well on the whole, but is apt to cause a great deal of cramp. This effect can be lessened by adding novocaine to the solution. Perivenous injection is very painful, and may lead to extensive necrosis. As this substance is non-toxic, a great many varices can be treated at one sitting.

Iomholt $t^{36}$ reports a case of death after injection of strong Sod. Chloride solution.

Meisen's Solution: Meisen clairs that this gives very successful results. When he used 25 c.c. of it at one sitting, he found that embolus might result and he now states that $10 \mathrm{c.c}$. is his maximum dose, and with this he says no embolus follows.

We have never used this mixture. It seems preferable to use a single substance only, as the reaction is then definitely known. polypharmacy is best avoided in intravenous injections.

Qlucose: Acts very well in certain cases, but in others its effects are uncertain. It is a useful substitute for other injections, just as Citrate of Soda is. 
29.

It has been combined with sod. Chloride, but not always with happy results. Olson $3^{37}$ reports a case of embolus with fatal reault following the injection of this mixture.

It is non-toxic, and thus is suitabie for treating a large area at one consultation.

\section{SUMRAARY.}

The above are the chief substances used in modern treatment. Hy preference is for two of them. Sod. Sal. and quinine. My ordinary practice is to use Sod. Salicylate. Pirst. Should, however, it Iail, as it sometimes does with the larger varices, Quinine is substituted, and this will practically always cause a successful result. If patients have extensive varices, and a quick result is necessary, the quinine is used from the first. It is, however, necessary to warn them that this treatment may compel them to rest in bed for a few days.

Quinine is also used instead of Sod. Sallcylate when the patient is unable to endure the cramps which follow the injection of the latter substances. 
It is essential to have perfect asepsis, and it is very important that the solutions of the substances injected should be made up by a reliable firm.

In my practice I use a very fine needle (No.19) and a 2 c.c. Record Syringe. These are sterilised by boiling. It is important that the bevel of the syringe should be short, as this allows the point to remain in the vein without pieccing the opposite wall. The point must be very sharp so that the vein is not torn. This helps to prevent leaking of blood.

The skin is disinfected with absolute alcohol.

Position of Patient: Where possible sitting on a high couch with the legs hanging over the edge. The operator can then sit on a low stool.

Cotton wool held in position round the ankle by an elastic band is a convenient way to catch any blood that trickles down the limb when the veins of the leg are operated on.

If the veins are not sufficiently prominent in 
the above position, the patient must stand up. This position is not possible for some very nervous patients. A tourniduet applied round the thigh when the patient is standing will make the veins sufficiently prominent for the patient either to sit or even to lie down. It is only when the veins are very laxge that it is possible to treat them satisfactorily when lying down without previously applying the tourniquet.

The injection: One begins with the lower part of the vein first. The needle attached to the syringe filled with the chosen solution is pushed into the vein through the sterilised skin in an upward direction. The piston is slightly withdrawn and if the point of the needle is within the vein, blood will flow into the syringe. As small a quantity of blood as possible must be allowed to enter the syringe in order to avoid diluting the solution. The solution is then injected into the vein.

The object is to act on the intima of the vein. One gets the best results when the injected vein is most empty of blood and a satisfactory way in practice is to run the ulnar border of the left hand upward from the 
site of puncture with slight pressure along two or three inches of the vein. It is kept there during the injection. Then the desired amount of the solution has entered the vein, the needle is kept in position for about half a minute and then withdrawn, the puncture being irnmediately pressed on by sterilised cotton wool, held in the fingers of the left hand, and the limb elevated. The pressure not only helps to lessen oozing, but also prevents the dilution of the injected liquid by the flow of blood from the distal part of the vein. The leg is kept elevated for 2 or 3 minutes.

Sicard ${ }^{38}$ recomends that the elevation of the limb should be a passive one. Should the patient raise the limb by muscular contraction there is the risk of drawing some of the injected fluid into the deep veins and setting up an inflammation in them. This opinion is based on the radio eraphic study of Lipiodol injected into the veins. He injected 1 c.c. Iipiodol into a dilated vein at the upper part of the leg. the patient being in the horizontal position. He noted that the Iipiodol tends to pass towards the foot, and as long as the patient does not move, it 
remeins in the superficial plexus of veins, but if he move his leg, either by making flexion or extension movements, or by walking a short distance, much of the Iipiodol is found in the deep veins.

Of course ny experience is nothing like that of sicard's but in hospital practice it is not always possible to prevent patients from moving their limbs aftex an injection, and so fax I have not seen any bad effects from their doing so.

If there is oozing at the end of that time when the leg is lowered, sterilised wool kept in position by an elastic band stops it and allows the operetor to proceed with further punctures.

Some operators use a differert proceeding. After the needle is in the vein, they raise the leg and then inject. This method is very good but requires care, lest the neede should pass out of the vein during the movement of the limb.

The first method ia the one I prefer and it has answered very successfully.

Filderman ${ }^{39}$ describes a method winich he says is very useful when there are in addition very fine varices which cannot be treated directly. The needle is passed into the vein with its point directed downwards in the direction of the foot and 5-10 c.c. of a 
20-30\% Sod. Sal. solution are injected. This method is painful and requires the use of novocaine. We have never attempted it.

The method of Bardy 40 (1igature of the saphenous vein and injection of large quantities of Pregl's iodine solution) does not corne within the scope of this paper. He is satisfied with his results.

\section{Results of Ireatment.}

\section{Clinical.}

The patients very early in the treatment experience a sense of relief in their legs. The feeling of weight and the pain disappear.. It is curious to note how this relief is noticed after only a few of the veins have been successfully treated. The appearance of the leg is much inproved, and any oedema is greatly lessened or disappears. Varicose ulcers and skin eruptions are a.so gxeatly benefited. Indeed this treatment is the foundation of a successful result in these conditions. It helps the action of other remedies.

As regards the question of embolus resulting from the the treatment, I have never yet seen a case and neither, as far as 
I am aware has sicard, Paraf or Generrier. The experience of these three is enormous, and they have not reportea a case. An injection which is not properly performed especially as regards asepticity, may lead to the formation of a septic tinrorabus. Inis is not the fault of the treatinent, but of the operator. Another case in which embolus may occur is when a mixture of substances is injected into the vein, e.g.. Calirose and sod. Chloride, or Sod. Sal. and Sod. Chloride as has been previously mentioned. It is in my opinion much better to inject only one drug. One has then to deal with a definite reaction.

I do not think that the statement so frequentiy made that any embolus would tend to pass peripherally on account of the reversed flow of the blood in varicose veins is tenable.

So long as the patient is erect it may be so but there are positions in the patient's daily life when the normal direction of the blood current is resumed which would at once favour the passage of an embolus into the general circulation.

The claim that embolus does not occur must rest on the fact that the thrombus is so firmly adherent to 
the ressel wall that it cannot be detached.

The injection of the substance into the perivenous tissues or the passage of blood mixed with the injected substance into the tissues outside the vein, may cause very violent reactions attended with great pain and crippling. The remedies for these are obvious. A sharp needle, strictly intravenous injection, not too much haste in withdrawing the needle and firm pressure while the needle is being withdrawn.

\section{Microscopical.}

The result of the intravenous injection of any of the previously mentioned substances is to set up an aseptic phlebitis. The venous wall becomes markedly swollen, all the coats participating, and in some cases the inflamation extends beyond the adventitia. Ihis can be noted clinically in cases where the overlying skin becomes red.

The endothelium of the intima becomes swollen and in places desquamates. Its cells can be seen detached in the lumen of the rein. Over the area of damaged endothelium a clot is forred which is very firmly adherent. This clot is soon invaded by young vessels and 
37.

connective tissue cells. The acute congestion of the venous wall passes off and as a result of the proliferation of the connective tissue cells in the various coats of the vein, ultimately the vein is transformed into an impermeable fibrous cord/which all traces of the original structures (e.g. muscular tissue, elastic lamina, etc.) have practically disappeared.

A minor point may be mentioned. It has been found that in sections of veins which have been injected two or three days previously the elastic fibres are ruptured and Bazeles ${ }^{41}$ suggests tentatively that the painful cramps which follow intraverious injection may be due to their sudden rupture. This is hardly likely as the cramps occur especially after treatment with sod. Salicylate and are not noticeable as a rule with quinine or Biniodide of Mercury. As mentioned above. I think they are reflex due to the special irritating action of the Sod. Salicylate.

Sicard in his numerous works refers to the changes in the veins as a veinite, and in his earlier writing he uses the term "endoveinite" which seems to imply an inflamation limited to the intima of the vein. 
38.

I do not think that it is necessary to introduce a new term for the inflammation caused by these injections. The term phlebitis is the pathological name consecrated by custom and the facts that it is caused in this case by a chemical substance and that it is aseptic are surely not enough to justify a new pathological name. As regards the term endoveinitis, Sicard, as mentioned above, is more inclined to replace it by ${ }^{6}$ veinite' in his latest work ${ }^{42}$ especially since the experiments of Jentzer of Geneva 43 , who injected into veins of rabbits and of man, solutions of Sodium Salicylate mixed well with collargol. The veins were excised 2 days, 4 days, 8 days, and 12 days after the injections. The collargol was found to have penetrated all the walls of the vein and had reached even the perivenous tissues. A reason$a b l e$ inference was that the sod. Salicylate must have done so also.

Apart from this the various microscopical examinations made lately have shown that all the venous walls take part in the process. As mentioned above, after an injection, there is great swelling of the venous walls and it is possible that in the smaller veins this swelling 
is sufficient, to completely obliterate the lumen without any clot being formed.

Anong the various writers who have done experimental work on this part of the subject and who have also had opportunities of examining the vein in man mey be netioned Regard ${ }^{44}$, Delater and Huger ${ }^{45}$, Meisen 46 , Bardy ${ }^{47}$. Montpellier Iacroix and Boulin ${ }^{48}$, Sicard ${ }^{49}$. Humbert ${ }^{50}$. The work of Jentzer had just been referred to. The work of Jentzer had just been reperred to. 


\section{Contra-indications.}

Judging whether or not the attempt to cure the veins should be made is largely a matter of medical knowledge, plus common sense.

If the cause of the enlarged vein is some obstruction from a pelvic or abdominal tumour, the obvious remedy is to remove the tumour first, allow a reasonable time to elspse and then treat any ramaining enlarged veins. In cases of pregnancy the same rule applies, even in those cases where the veins are enormously distended and seem as if some of them would burst, the case is beat treated by rest in bed and bandaging. When the patient cannot lie in bed as much as is desirable, the application of a zinc gelatine dressing or bandage impregnated with zinc gelatine is all that is necessary to be done in the majority of these cases.

Should however rupture of a vein seem inevitable, it can be obliterated by one of the above mentioned substances, and a severe haemorrhage avoided. Quinine of course must not be sued for this purpose as it nay cause abortion.

The same methods apply to cases of heart disease where 
compensation has broken down. Treat the heart condition first, and deal with the veins afterwards if necessary. I do not consider that high blood pressure caused by renal disease, arterio-sclerosis etc., is a necessary contra-indication. The case nust be looked at as a whole, and if efforts to relieve the blood pressure are unsuccessful, and the veins are adding to the patient's distress, I should certainly obliterate them.

There is one condition where I consider that this should not be done and that is where there is definite indication of phlebitis of the deep veins of the $l e g$. An attempt to do so is, in my opinion, wrong as it has been found by experience that it is apt to light up the old inflammation. Besides the varicose veins in this case are to be regarded as a compensatory enlargement. and to obliterate them would only increase the patient's distress. The best treatment is to support them by properly applied bandages.

In this connection, although somewhat apart from the subject of the paper, may be mentioned the condition termed wy Vaquez. Ia Septicemie veineuse subaigule $e^{51}$ and studied also by Legrand. $\overline{52}$ This condition, according to sicard, is frequently cured by intravenous injections of Sod. Salicylate, 
but the strength should be weak, only $5-10 \%$.

Patients with varicose veins are often subject to localised attacks of phlebitis in them and the question arises; Is it safe to use the injection treatment? Certainly it ought not to be used unili the attack of Phlebitis has completely disappeared. When this has done so the veins can be cautiously treated. The solution employed should be weak, e.8. 10-15; sod. Salicylate and the amount injected should not be more than $2 c . c$. The treatment should not be given oftener than once a week at most.

The reason for this care is that the veins undex these circumstances have been found by experience to react much more than usual to itritants, so that the stronger solutions usually employed cause exceedingly serere sequelae.

Injection of course will not be made into the veins near a septic ulcer of the leg or through skin which is inflamed.

Another condition which is best left alone is when there are numerous small dilated venules. These are disfiguring of course, and the leg often feels spongy and 
swollen. There have been attempts made to cure thein, but personally I refuse to treat them unless there are large dilated veins which seem to ve the cause of the dilatation of the venules.

I also avoid treatment in alcoholics and in cases of diabetes.

\section{Sumrary.}

There is one absolute contra-indication, i.e.. previous phlebitis of the deep veins. In all other cases the operator must combine judgment and knowledge of general medicine, and if there are other methods of curing or relieving the varicose condition, he ought not to allow his zeal for the injection method of treatment to outrun his discretion. 
The advantages of this method of treatment.

1. It is safe, So far I know of no case of embolus in cases treated on the lines I have indicated.

2. It is ambulatory: The patient can remain at work. It is unly in a small percentage of cases that rest in bed is necessary and even then two or three days are sufficient. $\quad 0 \hat{I}$ course I exclude here those patients whose mentality urges thern to go to bed when they suffer the slightest pain or inconvenience.

3. It is curative: if the patient will persevere one can guarantee a cure in all those cases where proper selection and judgment have indicated the necersity for treatment. 


\section{General Summary.}

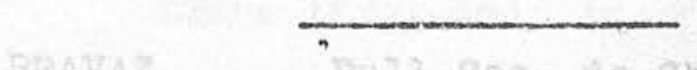

1. Proper selection of cases must be made.

2. Speaking generally, use Sod. Salicylate first.

3. Quinine to be used when time is an object, when the veins are very large, when Salicylate has failed, or causes too much cramp.

4. If either Salicylate or quinine is contra-indicated, e.g. from idiosyncrasy, etc.. any of the other solutions may be used.

5. The cases in which either Salicylate or quinine fail are exceedingly few.

6. A cure can always be promised in properly chosen cases, without the patient having to give up work, or at the most only for a few days.

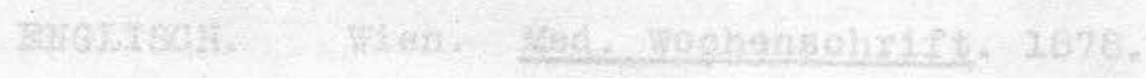
TBROCA.

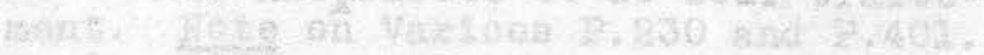

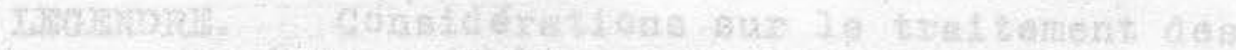

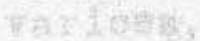


1. PRAVAZ. Bull Boc. de Chir. 1851. 1ii.

2. HIPPOCRATES. Transl. Adams. Vol. ii. 2808. Syd. 50c. 1849.

3. CrLsUS. De medicina. Lib. vii. Cap. XXXI. De varicibus.

4. AVICBMA. Canon Medicinae. Iib. iii. fol. 400. Venet 1555.

5. PAUJIIS ABGINISPA. Opera medica. Transi. Adans. Vol. 1i. Sect. LXXXII. P406. Syd. Soc.

6. AMBROTSH PARt. Oeuvres. Book. 13. Chap. XX.

7. VAJETTI. Lettre à la societé de chirurgie, 27 Juiliet, 1853.

8. PITRTEUIN. Gaz. Med. de Paris. 1853, p.625.

9. CHAISSAIGNAC. Résultets obtenus à i'Hopital SaintAntoine par les injections de perchlorure de fer dans les varices. Gaz. Hebd. de Méd.. $1853-54$. p. $401-403$.

10. IESGRAIGES. Injections iodotamiques dans les varices. Mern. de la Soc. de Chir.. 1885, iv.

11. ERGJISGF, Wien. Ifed. Wochenschrift. 1878.

12. BROCA. Des Anevrismes et de Ieur traite-

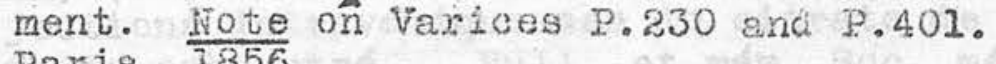
Paris, $\overline{2856 .}$

13. IJGHERE. Considérations sur le traitement des varices. These de Paris, 1881.

14. TAVIDI. Traitement opératoire des varices. I,XXIIe congres de I'Ass. centrl. de Medecins Suisses, Oct. 1904. 
15. SCHIASSI, (B). La cure des varices au membre inferieur par les injections intraveineuses d'une solution d'iode. Serarine med. , 2908, xxviii, 601.

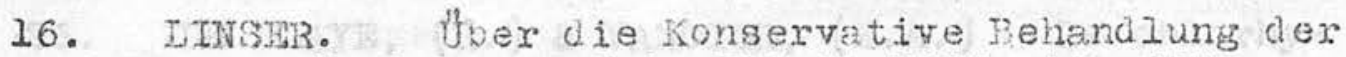
Varicen. Med. Klinik 1916, 12, 897.

17. SICARI, (J.A.) \& ROGIER, (H) Présentation des - malacies du Conité méd. des Bouches-duRhớne. Harseille méd.. 1919.

18. SICARD, (J.H.) \& ROGER, (ii). Iraitement des varices par injections intra-veineuses locales de carbonate de soude. Larsejile med.., IVii, $97-103$.

19. SICARD, PARAF \& IERUOYHSs. Jes injections intravarique-uses de saificylate de soude. XVIe Congres de Medecine, 192\%. Objection Coury, presse méd. 1922, $\mathrm{xxx}, 026$.

20. GKNTRISR, (J.) Du traitement des varices par les injections coagulantes, concentrées, de sels de quinine. Soc. de méd. milit. frang.
1921, $x y, 169-171$.

21. GHiftrim. Les injections intravasiqueuses coagulantes de quinine. Monde med.. 1922, xxxii. $624-627$.

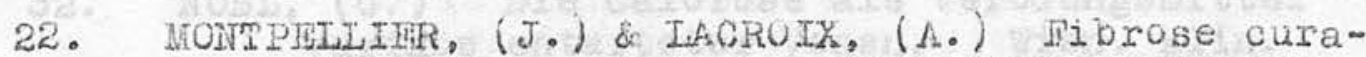
tive des varices par injections intraveineuses locales de bilodure de HE. Bull. soc. franc. de demat. et syph. . 1921. xxviii, $473-475$.

23. MROISIDR, (J.) La cure aes varices par tes in. jections intravariqueuses de citrate de soude concentré. Bull. et mér. \$oc. méa. d. Hôp de paris, 1924, 3.8. xiviti. $682-686$.

24. TROISIRR, (J.) Les applications modernes du citrate de soude en therapeutique. Concours méd., 17 aoút. 1924. 
25. VANDIMR. Les injections intravariqueuses. These de Paris, mai 1926.

26. IIT BIAYT, $\left(\mathrm{R}_{\text {. }}\right)$ \& VANDIHR, (E.A.) Le chlorhydrate double de quinine et d'urée. Ses applications thérapeutiques à la cure des varices. Bulletin médical, 1927, xli. 289.

2\%. IINSER, (K.) zur Behandlung der Varizen mit intravenosen Injektionen. Munchen.med. Wehnschi., 1924, Ixxi, 515.

28. -..... Die Behand Lung der Krampfadern. Therapie d. Gegenw. 1925, 1xvi, 29-23.

29. MTISEN, (V.) Injektionsbeharding af Varicer og deres Folgestilstande. Ugeskr. f. Laeser, 1925, Ixxxvi1, $929 ; 964$.

30. Injektionsbehanding af Varicer og deres Jolgetilstande. II. Ugeskr. f. Laegex, 1927, 1xxxix, 47-56.

31. RTMETOVSKY, (I.) \& KANIOR, (R.) dirie neue Methode der Varizenbehandlung mit 50\%iger Traubenzuckerlosung. Wien, ki in. Wchnschr. , 1925, xxxviii, 532-535.

32. NOBI, (G.) Die Calorose als Verodungmittel variko entarteter Venen. Wehnschr., 1926, xxxix, 1217-1219.

33. DIPTATER, (G.) Des incidents de choc au cours de la fibrose curative des varicea. Presse med.. 15th Oct., 1927, No. 83.

34. AIMAS. Letter to Presse med. 13th Aug.. 1927, No. 65 .

35. JORGMHSH. Salicyforgiftning efter intravenos injektion af Natriumsalicylat toed Behand lung af varicer. Ugeskr. f. Laeger, 1928, xc, 31.

36. IOMHOIT, (3.) Dodsfald af Tmbolia arteriae puImonalie efter Varicebehanding med koncentreret Kegsaltoph Ugeskr. f. Laeger. 1927 , $1 \mathrm{xxxix}, 7$. Kogsaltoplosncing 
3\%. OLSON, (O.A.) Fatality following varicose vein injection. J. Am. M. Ass., 1927, Ixxxix,692.

38. SICATD \& GAJGIFR. Je Traitement des Varices. Masson et cie. 1927.

39. TITDERMAN. The Modern preatment of varicose veins by I. Humbert. Paris, 1927.

40. BARDY, (H.) Finsira. Lah-SaIIsh, Hand1.. 1924, Ix>i, 46-52.

41. BAZJIIS. maitament des Varices. Thèse de Paris. 1925.

42. SICARD EMT GAUGIBR. Traitement des Varices. Masson et Cie. Paris. 1927.

43. JMNTZFR. Les injections phlebosclerosantes de salicylate de soude (Hethode de J.A. Sicard) Contribution anatomopathologique. 33 e congres de Chir. de Paris, 1924, p. 741 .

44. REGAND, (G.I.) Le traitement des varices par les injections sclérosantes. Rev, Med. de la Suisse Romande, 1925, xLV, 102-10\%.

45. DIFIATER, (G.) \& HUGEL, (R.) Six propositions fondamentales sur la pathogénie et le traitement des varices des membres inferieurs. Monde Médical, 1926, xxxvi, 14-20.

46. HATISET, $\left(V_{0}\right)$ Op. cit.

47. BARDY, (น.) Op. cit.

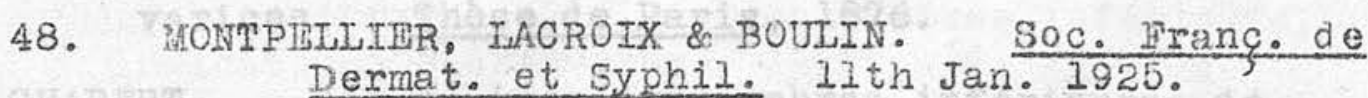

49. SICARD \& GAUGIRR. Traitement des Varices. Masson et Cie..1927.

50. HUMBTHR. (L.). Les réactions inflanmatoires á la suite des injections sclérosantes intravariqueuses. Hơpital, 1927. KV, 77. 
51. VAQUHZ, (H.) \& LBCONTH. Ia Septicémie veineuse subaiguë. Presse Medicale. 192l. xxix, 273.

52. LFGRANT, (c.) La septicémie veineuse subaiguë. Revue de Hédecine, 1925, xlii, 169-178.

The following aditional references which are not mentioned in the text will be found cf interest, especially the papers which give the personal experiences of the writers in carrying out this method of treatment.

GAUTHIBR. Considérations critiques sur le traitement des varices. De leur traitement par les injections de liqueur iodotannique. shese de Montpellier, 1860.

ROUBY. Du traitement des varices et spécialement du procédé par les injections de liqueur iodotanniques. Inese de Paris. $186 \%$

VALTERII. Cliniques chirurgicales Hotel-Dieu de Lyon. Baililere, edit. 1875.

MICHAUD. Thtude sur le traitenent cuxatif des varices. Phese de Paris, $18 \% 6$.

CHABERT. Des varices des membres inférieurs, de leur traitement et partculidrement des injections periveineuses. These de Paris. 1879.

IFIOMBE. Du traitenent du prolapsus rectal et de la procidence hemorroidale par les injections hypodermiques d'ergotine. These de Paris, 1880. 
FATIN. Considesrations sur le traitement des varices. These de pario, 1830.

LACARRIGUE. Contribution á l'etude du traiternent des tumeurs variqueuses par les injections coagulantes. These de Paris. 1880.

SCHWARTZ, (․) Article "Varices" Nouveau Dict. de MEd. et Chir. prat., Bailijere, Paris, 1883.

CAIILONAs. Contribution à I'étude de la cure des varices. These de Paris, 1898.

GUIDENSCHUH. Phlébite variqueuse et en particulier de son influence curative sur les varices. these de Montpelijer. 1893.

RAMY. Traité des varices des membres inférieurs. Paris, Vigot. edit. 1902.

CANAPRIPR, (P.A.) La clinique des varices des membres inférieurs. Thesse de Bordeaux, $190 \%$.

SCHIAGSI, (B.) The treatment of varicose veins of the lower linb by intravenous injections of iodine. Hed. Press \& Circ.. 1909, n.s.. Ixxxvii, $37 \%$.

WIDAI \& BEZANCON. Nouveau Traite de Hédejne de BrouardeI? xxr, 191 I.

DARRIRR \& COMTENOY. Action nocive sur les veines et sur le sang des injections intra-veineuses hyperalcalines d'arsenobenzol. Bull. et mém. Soc. méd. d! Hôp. de Paxis, 1911, 3.s., xxxi, $415-426$.

DTIBIT \& MOCquOT. Varices des mernores inferieurs; indications operatoires, I. de med. interne. 1913, xvi1, 171.

MIBRGARI. AVvelenamento dal iodo nelia cura delle varici alla Schiassi. Gaz. Med. di Marche. Ancona. 1913, xxi, 1.

SCHIASSI. NuOvo metodo italiano quale trattamente delle varici dell arto inferiore. Bologna. 1914. 
ACHILIE, (F.) Contributo alla cura delle varici degli arti inferiori, secondc il metodo Schiassi. Gazz. d. 0sp., 1916, xxxvii, 1570-1574.

STHWARM, (D.H.) The ambulant treatment of varicose veins. Hed. Press \& Circ., 1916, n.s., ci, 11.

ZIRI, (C.) Iyie Behandlung der Krampfaderr mit intravenosen Sublimatinjectionen. Dexmat. 2tschr. 1916. Orig., xxiii, 193-211.

CIASFN, (F.F.) Taricen und VIcus crucis und ihre Behandung als "Spezialität" İur den praktischen Arzt. Hed. Klin., 1918, xiv. 768; etc.

A

KAPPIBLAN, ( . W.) Injection of hot sodium chloride solution in treatment of varicose veins. J. Am. If. Ass., 1919, 1xxii, 1216.

PUTzU, (F.) La cura delle varici degli arti inferiori col metodo Schiassi. Clin. chir., 1919, n.s. i. $1272-1279$.

WEIIS. (H.O.) The cure of varicose veins without surgery. Hed. Summary, 1919, xl1, 80.

ZIRN, (C.) Ueber die Behandlung der Krampfadern. Krampfaderbrüche, usw. mit intravenósen sublimatinjeiktionen. München. med. Wohnschr, 1919, 1xvi.382.

BONNJF. Les injections intra-variqueuses de carbonate de soude. These de Paris, 1920.

CROUX, (2.) Contribution a I'etude du traitement des varices du membre inferieur. These de Mon'tpelifer, 1920 .

ROGHR, (H.) quelques mots d'historique d̀propos des injections intravariqueuses. Commun. du 23 janvier 1920, à la Commission scientif. au Comité rédical des Bouches-du-Rhone.

SICARD, (J.A.) \& PARAF (J.) Traiternent des varices par l'injection intravariqueuse de carbonate de soude. Bul1. et méml dínop. de Par.., 1920. xliv, 1369-1375. Sâ.med. 
DELBET, (P.) Varices. Progres med., 1921, xxxvi, 463.

RHRMNPREIS. Traitement des varices par la méthode de Sicard. J. de Méd. de Paris., 1921, xl. 584.

GTNIVRIBR. Du traitement des varices par les injections coagulantes concentrées de sels de quinine. Bul1. de la Soc. de Méd. Militaire franc.. 1921.

GUIIIJMERT. Vlceres variqueux traités par la methode ambulatoire. These de paris, 1921.

LECONTE, (M.) Notions récentes sur les phlebites. J. med. franc.. 1921, x. 366-370.

MINET, AUSSET, DUTHOIT. Traitement des varices par les injections intraveineuses locales. Nord. méd.. ler juillet, 1921.

MONTFAECON. Article "Varices". Dictionin. des Sciences med.. Paris, Pankouckep 1921.

PASCHOUD, (H.) Traitement des ulceres variqueux. $\frac{\text { Xxxe Congres franc. de chir.. Strasbourg. }}{1921,0.439}$.

PROUST, LHERMITTE \& DE NABIAS. Pathogénie des ulcères variqueux. Soc. de Chir., 8 juin, 1921.

SICARD, (J.A.) PARAF, (J.) \& FORBSTIBR, (J.) Le traitement des varices par les injections intravariqueuses de carbonate de soude. J. méd franc., 1921, $x, 377-384$.

SICARD, (J.A.) PARAF, (J) \& IORASTIER (J). Pathologie des veines. Dies injections intraveineuses. J. med. franc.. 1921, $x$.

BBLIOT, (V.J.) Cure radicale des varices par les injections intravariqueuses de quinine-methane. Arch. de méd. et pharm. nav., 1922, cxii, 378-399.

BIPNCHPMOUL. Fibrose curative des varices par le biiodure de mercure. These d'Alger, 1922-23.

DUBREUIJH. A propos du traitement des varices par les injections de bilodure de mercure. Bull. Soc. Dermat., 1922, xxix, 92. 
GIORDANNI. Le traitement des varices par les injections intra-variqueuses de quinine uréthane. These de Bordeaux, 1922.

JANNGIII, (G.) La cura delle varici degli arti con le indezioni trombosanti. Studium, 1922, xii., 370-374.

Is BLAYE。 (R.) Le methode des injections intravariqueuses: ses difficultés et ses avantages.

Bul1. Soc. de méd. de la Vienne, 1922, 75-82.

IESND, HALIA, GUINON, etc. Emploi du salicylate de soude en injections intrawe ineuses. Soc. de Pédîtrie, Presse méd..1922, xxx, 586.

LUTHMBACHAR, ( $R$ ) Le salicylate de soude en injection intraveineuse. Corapt. rend. Soc. de biol. 1921. $1 \times x \times v, 421-423$.

MONTPIDIIIFR \& LACROIX. Fibrose curative des varices par le bilodure de mercure. Presse méd. . 1922. $\mathrm{xxx}, 342$.

QUISERNE (P.) Ie traitement medical des varices. J. de med. et chir. prat., 1922, xciii, 153-161.

SCHIMSSTR. Injections intra-veineuses de salicylate de soude. These de paris, 192?.

CIOTTENS: Modification technique a la méthode de Sicard pour le traiternent des varices. Soc. d. sc. méd. et biol. de Montpellier. 1922-23, iv.198.

FIIDFIRMANI. Traitement des varices par les injections sclérosantes intra-variqueuses. Soc. méd. des Praticiens, 1923. 
FORISSTIAR $(J)$. Le traitement des varices par les injections intra-variqueuses. Progres méd.. 1923, xxxviii, 3l-35.

HALIION (i.) Sur la physiologie pathologique et le traitement des varices. Rev, prat. de biol. (etc.) 1923. xvi, 225, 25\%. Alsotransl: Med. Press, 1923, n.8., cxvi. $52 \%-530$.

MATHIEU (A) Traitement des varices par les injections intravariqueuses de quinine. These de Montpellier, 1923. Marseille Med., 1923, 1x. $550-555$.

MICHAUX. Article "Varices". "Quelques médications récentes". I'Oeuvre méico-thérap. . Mars. 1923, p.60.

MONTPHLTIER (J), IACROIX (A) \& BOUTIN (P). Note au sujet de la fibrose curative des varices par les injections intraveineuses de bijodure de mercure. Bul1. Soc. franc.
de dermat. et syph. $1923, \mathrm{xxx}, 53-56$.

OKINCZIC. A propos du traitement des ulceres variqueux. Soc. de Chir.. 21 mars, 1923.

QUISERNT (P) I'opotherapie dans le traitement médical des varices. Méd. órat., 1923, xxx, 227-232.

BACHARACH (A.) Traitement des varices par la methocie phlsbosclérosante. Association novocainese. Progrès. méd. 1924, 11. 500 .

BHRTONE (C) Uebex der Unterbindung der Kniekshlenader bei Aderkröpfen nach Parona. Kasuistisher Beitrag. Acta Chix. Scandinat. 1924. Ivi., 539-554.

COUDRAY (G.) Traitement des varices et des hemorrhoides au moyen des injections sclerosantes. J. de méd. de par. 1924..xliii. 904-90\%.

FORESTIFR (J.) Traitement des varices des nembres inferieurs par les injections intravariqueuses. Clinique. 1924. $x i x, 274-276$.

GLIY \& MAIGRT. Du traitement des varices par injections sclérosantes. Concours méd.. 2 nov., 1924. 
HALIION (I.) Technique des injections sclérosantes dans les traitement des varices. Revue Biol. Appl., fev.1924.

HWHIPI (c.) Erfahrungen mit Sulolimatinjektionen bei

Varizen. Hunchen med. Wochnschr., 1924, 1xxi, 900-902.

HUMBGRT. Concours medica1, not., 1924.

KJAPP (R.) Ueber Varicen. Zentralbl. f. Chir., 1923. 1.947.

IINZER (K.) Zur Behandlung der Varizen mit intravenöser

Injektionen. Hunchen med. Wchnschi., 1924, 1xxi. 515.

MoUzs (J.) Traitenent des hemorrholdes par les injections sclérosantes. Ihèse de paris, 1924.

POINCLOUX (P.) Traitement dea varices par injections intra-veineuses de solutions phłébosclérosantes. Bu11. med.. 18 juin, 1924.

CARNGP VIDICAT FRANCATS, Sept., 1924. Traitement des varices par injections intraveineuses de sulutions phlébosclerosantes.

GASTON (A.) Jes injections intra-variqueuses de salicylate de souke. Bèr. Bént de clin. et de thérap., 1925, $x \times x i x, 343$.

JOEY (P.R.) Du traitement des varices paz les injections sclérosantes; ses conséquences lointaines; ses indications. Evvolution med. chir.. 1925, vi, 72-76.

MARIY (P.) \& TRONCIN (J.) A propos du traitement des varices par les injections intraveineuses de citrate de soude. Rev. gén. de clin. et de thérap.. 1925. xxxix., $169-17 i$.

LinNORMANT (20.) A propos du traitement des varices par 1a méthode de Sicard. J. de Méd. de Par., 1925. xliv., 982 .

DUNBAR. Treatment of Varicose veins of leg by injections. B.M.J., 1925, i., 14-I5.

KOTMMAIER (B.) Die Linsersche Varizenbehandlung und ihr Wert flir die Dermatologie. Dermat. Ztgchr., 1925, xilii, 186-190. March. 
ROUET (M.A.) Várices y úlceras varicosas de los membras inferiores; las inyecciones esclerógenas; sus resultados. Semana méd.. 1924,xxxi, pt. 2, 1431-1445.

IINSBR. Die Behandlung der Varizen mit künstlicher Thrombosierung. Dermat. 2tschr.. 1925, xlv.. 22-27.

BARDY, (H.) Die Behandlung dex Krampfadern. Acta chir. Scandinar. 1925, Ivii1, $74-80$.

SCHLUNK, (F.) Zusarnmenstallung der wichstigsten therapeutischen Lassnahinen bei der Behandlung der Varizen und ihren Folge erscheinungen. Wunchen med. Wehnschr. 1925, Ixxii. 856-857.

IVANISSEVICH, (0.) [rreatment of Varicose Veins and of haemorrhoids with sclerosis causing substances.J Eemana méd. 1924, ii, 1093-1098.

WALTRR. THin Betrag aus der Praxis zur Behandlung von Varizen und Ulcera cruris, Munchen med. Wchnschr. 1925, xii. 1251.

KFHAR. Treatment of varicose veins by occlusion method. Indian M. Gaz. 1925, 1x, 265-266.

MPYER, (F.G.) Veher Varizenbehand lung mit den Linserschen Sublimatinjecktionen. Deutsche. Med. Wochnschr. 1924. 1. 1832-1833.

LINSER, (K.) Die Behand lung der Krampfadern mit intravarikösen Kochsalzinjektionen. Dermat. Wochnschr. 1925. 1xxxi。 1345-1351.

JUNG, (R.) Die Behandlung der Varizen durch intravenöse sklerosierende Injektionen. Schweiz med. Wochnschr. 1925, IV, 1100 .

DOUTHWATME, (A.H.) Treatment of varicose veins by injection. Brit. M.J., 1926, ii. 554.

ALEXANDER, (S.) Treatment of varicose veins by injection based on 14 months experience. Lancet. 1926, ii. $176-177$.

GAUGIHR, (L.) Le Traitement des varices par les injections sclérosantes (méthode Sicard). Rev. pratd. mal. d. pays. chauds 1926, $7 i, 389-404$. 
GAUGTrR, (I.) Le traitement des varices par les injecticns sclérosantes peut-il occasionner (ou provoquer) des phlébites ou des embolies. Hande Med., 1926, xxxr1, 699-704.

PARIDIANS. Varices traités par les injections sclerosantes (Soc. Belge de Chirurgie). 1926.

SICARD \& GAUGIHR. Le traitement des yarices par Ia methode aclérosante injections. Presse méd. 1926, xxxiv, 689-693.

IOMHOIT, (S.) \& GENNER, (V.) Om Behanding af Varicer paa Underextremiteterne og deres Folgetilstande med Injektion af en koncentreret kogsaltoplosning. Ujesk. fo Laegex, 1926, Ixxxviii, 771-776.

ALSTRUP, (K.) Orn Tekniken ved Injektionsbehandling af Varicer. Ugesk. f. Laeger, 1926, 1xxxviii, 550-551.

MPISFN. Technique for injection treatment with sodium salicylate of Varices. ActaChir. Scandinav. 1926, $1 x, 435-462$.

DIBIATIR, (G.) Fibrose curative des varices, propriftés de quelquesesolutions sclérogenes; utilité de les associer. presse méd. 1926, xxxiv, 693-695.

LEVENT, (R.) Le Traitement des varices par les injections sclerosantes. Gaz. d.I 150p. 1927, c. 160-162.

STOKIES, (H.) Injection treatment of varicose veins. Irish J. 1. Sc., 1927. 206.

BORCHERDS, (W.A.) Treatment of varicose veins by organic arsenic injections. Brit. M.J.. 1927. i. 375 .

HIRSCH. Ist die kunstliene Phrombosierung varikos entarteten Beinvenen ohne vorherige hohe isigatur der Vena saphena zulassig? Wien. klin. Wchnschr. 1926, xxxix, 1310 .

NOBI, (G.) Entgegnung zur obigen Darstellung. Wien. kiin. Wchnschr., 1926, xxxix, 1310-1311. 
STOTZIRR. Durfen wir Irampadem thrombosieren? Schweiz. med. Wohnschr., 1926, Ivi, 1076.

DOUnHWATM, (A.H.) The injection treatrent of varicose veins. London. Lewis \& Co.. 1927.

HUMBERT, (I.) The irodern Treatment of Varicose Veins. Paris, 1927. (Transi.)

THORIHIII, (R.) The treatment of varicose veins by injection methods. Practitioner, 1928, cxx. 